\title{
THE STUDENTS' KNOWLEDGE, ATTITUDES, AND BEHAVIOR IN LEARNING HISTORY AT PESANTREN BUYA HAMKA
}

\author{
Ristapawa Indra', Martin Kustati \\ 'Sekolah Tinggi Keguruan dan Ilmu Pendidikan (STKIP) Pesisir Selatan, Indonesia \\ Jl. Padang - Muko-Muko No.28, Pesisir Selatan, West Sumatera \\ E-mail:pawa_indra@yahoo.com \\ ${ }^{2}$ State Islamic University (UIN) Imam Bonjol Padang, Indonesia \\ Jl. Prof. Mahmud Yunus Lubuk Lintang Padang, West Sumatra \\ E-mail: martinkustati@uinib.ac.id
}

\begin{abstract}
This study aims to determine the implementation stage of history learning process for students at the Pesantren Buya Hamka; the stages of knowledge, attitudes, and behavior of students regarding nationalism and patriotism; and the correlation of leadership variables, school climate, teacher performance, and pesantren culture to history learning and also to students' knowledge, attitudes, and behavior regarding nationalism and patriotism. This study also aims to find out the significant influence of historical learning variables on knowledge, knowledge variables on attitudes and attitudes on students' behavior. This study combines survey research quantitative approach with descriptive, correlation, and regression methods. The results show there is a significant correlation between independent variables with historical learning variables and student knowledge variables about nationalism and patriotism. Meanwhile, there is no significant correlation between independent variables and student behavior variables. The results also show only the history of learning variables among the five independent variables that significantly influence the knowledge of nationalism and student patriotism. Student knowledge variables about nationalism and patriotism partially also affect changes in student attitudes, while changes in student attitudes do not affect linearly on changes in student behavior.
\end{abstract}

Keywords: history learning; knowledge; attitudes and behavior; nationalism; patriotism.

\begin{abstract}
Abstrak: Penelitian ini bertujuan untuk mengetahui tahap pelaksanaan pembelajaran sejarah siswa di Pesantren Buya Hamka Kota Padang; tahap pengetahuan, sikap dan perilaku siswa berkenaan dengan nasionalisme dan patriotisme melalui pembelajaran sejarah; dan korelasi variabel kepemimpinan, iklim sekolah, kinerja guru dan kultur pesantren terhadap pembelajaran sejarah dan juga terhadap pengetahuan, sikap dan perilaku siswa berkenaan dengan nasionalisme dan patriotisme. Kemudian, penelitian ini juga bertujuan untuk mengidentifikasi pengaruh signifikan variabel pembelajaran sejarah terhadap pengetahuan, pengaruh variabel pengetahuan terhadap sikap dan pengaruh sikap terhadap perilaku siswa. Penelitian ini perpaduan penelitian survey dengan pendekatan kuantitatif dengan metode deskriptif, korelasi dan regresi. Hasil penelitian menunjukkan terdapat korelasi signifikan antara variabel indenpendent dengan variabel pembelajaran sejarah dan variabel pengetahuan siswa tentang nasionalisme dan patriotisme. Sementara itu, tidak terdapat korelasi yang signifikan antara variabel independen dengan variabel perilaku siswa. Berikutnya hasil analisis menunjukkan hanya variabel pembelajaran sejarah diantara lima variabel indenpenden yang berpengaruh secara signifikan terhadap pengetahuan nasionalisme dan patriotisme siswa. Variabel pengetahuan siswa tentang nasionalisme dan patriotisme secara parsial juga berpengaruh terhadap perubahan sikap siswa, sementara perubahan sikap siswa tidak berpengaruh secara linear terhadap perubahan perilaku siswa.
\end{abstract}

Kata kunci: pembelajaran sejarah; pengetahuan; sikap dan perilaku; nasionalisme dan patriotisme.

\section{Introduction}

All countries in the world agree that the national goal is to educate the lives of the people of the nation; therefore the government is responsible for providing decent, equitable, and high quality education services to all levels of society without discrimination. These steps are conducted by compiling long-term, secondary, 
and annual education plans which are spelled out through strategic programs and policies.

The objectives of national education are comprehensively achieved through several subjects that are concretely regulated in the content standards of national education. Some general subjects are intended to develop students' potentials in scientific aspects, while religious subjects are intended to develop students' potentials to become faithful, devoted, and noble, while efforts to develop students to become democratic, nation-oriented human beings, having a high spirit of nationalism and patriotism certainly can be realized through historical learning1. Bardansyah $^{2}$ states that the history course is a subject that instills knowledge, attitudes, and values regarding the process of change and development of Indonesian society in responding to the development of global society. It is then confirmed by Mestika Zed ${ }^{3}$ who states that history lessons at school aim to make students gain the ability to think historically and understand history. In the other hand, ${ }^{4}$ presents that the functions of history lessons are make students aware of the process of change and to develop society in the time dimension and to build a perspective of historical awareness in discovering, understanding, and explaining the national identity in the past, present, and future in the midst of global change. ${ }^{5}$ Various function of history lessons have at least provided an understanding of the importance of the past for the future.

Furthermore, Mestika Zed ${ }^{6}$ explains that history has a strategic meaning in shaping

1 Hermanu Joebagio, Madhan Anis, Husain Haikal, "Implementasi Wawasan Kebangsaan Dalam Pembelajaran Sejarah Di Pondok Pesantren," Society, (2013), pp.11-22.

2 Desvian Bandarsyah, "Fondasi Filosofis Pendidikan Sejarah Di Era Post Truth," Historia: Jurnal Pendidik Dan Peneliti Sejarah, vol. 3, no. 1 (2019), pp. 65-74, https://doi.org/10.17509/ historia.v3i1.21042.

${ }^{3}$ Mestika Zed, “Tentang Konsep Berfikir Sejarah," Lensa Budaya: Jurnal Ilmiah Ilmu-llmu Budaya, vol. 13, no. 1 (2018), pp. 54-60, http://dx.doi.org/10.34050/jlb.v1311.4147.

4 Suswandari, "Paradigma Pendidikan Sejarah Dalam Menghadapi Tantangan Masa Depan," Jurnal Cakrawala Pendidikan, vol. 1, no. 1 (2010), pp. 331-42, https://doi. org/10.21831/cp.v111.216.

${ }^{5}$ I Gde Widja, "Pembelajaran Sejarah Yang Mencerdaskan : Suatu Alternatif”, vol. 1, no. 2 (n.d.), pp. 117-34.

6 Mestika Zed, "Tentang Konsep Berfikir Sejarah..., pp.54-60.
Indonesian people who have a sense of nationalism and love. Historical lessons also have a socio-cultural function, arousing historical awareness. Based on this historical awareness, national consciousness was formed. The purpose of the subjects themselves is to foster awareness in students as Indonesian citizens who have a sense of pride and love for the nation, to have empathy and tolerance that can be implemented in various fields of community and nation life. Hunt (2007) explains that according to the result of History Working Group, there are nine objectives of learning history in school, including: (1) To understand the present in the context of the past, (2) To arouse interest from the past, (3) To provide students 'identities (nationalities), (4) To help give students an understanding of their roots and cultural heritage, (5) To contribute to students' understanding and knowledge of different countries and cultures in the modern world, (6) To train the mind with the study of historical disciplines, (7) To introduce students to typical historical methodologies, (8) To encourage other parts of the curriculum, (9) To prepare students for adult life. The nine objectives of studying history at the school, contain both dimensions of the usefulness of history learning in a practical level, namely as a medium to build the nation's identity, as well as the dimension of training students in the abilities unique to the discipline of history itself?.

According to the Regulation of the Minister of National Education Number 22 of 2006 the subjects of History must, first, contain the values of heroism, example, pioneering, patriotism, nationalism, and an unyielding spirit that underlies the process of forming students' character and personality. Second, it must contain treasures about the civilization of nations, including the civilization of the Indonesian people. Third, it should instill awareness of unity and brotherhood and solidarity to be the nation's glue in facing the threat of national disintegration. Fourth, it can be load with moral teachings and wisdom

7 Muhammad Maman Sumaludin, "Identitas Nasional Dalam Buku Teks Pelajaran Sejarah,” Historia: Jurnal Pendidik Dan Peneliti Sejarah, vol. 1, no. 2 (2018), p. 97, https://doi. org/10.17509/historia.v1i2.10709. 
that are useful in overcoming multidimensional crises faced in everyday life. Last, it should be useful for instilling and developing a responsible attitude in maintaining environmental balance and preservation. In other words, history learning has an important role in shaping the nationalism and love of land to students as future leaders. ${ }^{8}$

However, today the success of learning history is still being questioned, the history subject seems to have failed in realizing youth generation who are patriotism and nationalism? ${ }^{9}$ Their understanding of nationalism seems to have escaped from Indonesia's past history that Indonesia's independence was not a gift but the result of the struggle of the nation's heroes in freeing Indonesia from imperialism and colonialism. ${ }^{10}$ This generation seems to forget the facts which show that in approximately 70 million Indonesian people in the early independence consist of $90 \%$ Muslims and $10 \%$ non-Muslims. ${ }^{11}$ The formulation of the Jakarta Charter which was agreed as the basis of the state with the first revision of the precepts into the saying "Ketuhanan Yang Maha Esa - Belief in the one and only God" is a fact of the attitude of Muslims' tolerance. ${ }^{12}$ The current condition is that the young generation is not just not understanding, they are at a stage where they do not have the knowledge and care about national history. ${ }^{3}$

\footnotetext{
${ }^{8}$ Leo Agung S, "Berbasis Pendidikan Karakter Di Solo Raya ( Development History of Sma- Based Learning Model in Solo Raya Character Education )," Jurnal Pendidikan Dan Kebudayaan, vol. 18, no. 4 (2012), pp. 412-26.

9 Desvian Bandarsyah, "Fondasi Filosofis Pendidikan..., pp. 1-10, DOI: 10.17509/historia.v311.21042

10 Windy Putri Widayanti, Armaidy Armawi, and Budi Andayani, "Wawasan Kebangsaan Siswa Sekolah Menengah Atas Dan Implikasinya Terhadap Ketahanan Pribadi Siswa (Studi Pada Siswa Sekolah Menengah Atas (SMA) Umum Berasrama Berwawasan Nusantara, SMA Umum Di Lingkungan Militer Dan SMA Umum Di Luar Lingkungan Militer Di K," Jurnal Ketahanan Nasional, vol. 24, no. 1 (2018), p. 1, https:// doi.org/10.22146/jkn.32229."uri":[“http://www.mendeley. com/documents/?uuid=5d56ac8e-6ac4-4f67-bd83-6f3c812c26 4a"],"itemData":\{“DOI”:"10.22146/jkn.32229","ISSN":"08539340","abstract":"ABSTRACTThis study examined about the national insights students of boarding senior high school and its implications to the personal resilience of students Indonesia archipelago vision (SMA A

${ }^{11}$ Suswandari, "Paradigma Pendidikan Sejarah..., pp. 27-401

${ }_{12}^{2}$ Magdalia Alfian, "Pendidikan Sejarah Dan Permasalahan Yang Dihadapi," Jurnal Ilmiah Kependidikan III, no. 2 (2011), pp. 1-8, https://doi.org/10.30595/jkp.v3i2.643.

${ }^{13}$ Akhmad Arif Musadad, "Model Manajemen Pembelajaran
}

It is no secret that many young people have no idea about the history of independence, and do not even understand Pancasila as the national ideology and the nation's way of life. Many research results show that historical education as a process of fostering a national outlook, is still very alarming. ${ }^{14}$ The depletion of nationalism and patriotism, the lack of intolerance among fellow citizens is the latest condition regarding the growing apathy of the younger generation towards Pancasila, nationalism and patriotism. The results of this study indicate history lesson at schools has failed to instill a spirit of nationalism and patriotism for students as part of the nation's young generation. ${ }^{15}$

The decline spirit of nationalism and patriotism has become a hot national debate among academicians at the university level, government, and politicians. Even recently in the final round of Putri Indonesia pagean in 2020, to test the knowledge and understanding of the nationality of a participant, the Chairperson of the Indonesian People's Consultative Assembly was asked by the committee to ask light and simple questions about the precepts of Pancasila to one of the participants. The results were very surprising; it turned out that a participant did not memorize the precepts of Pancasila which netizens viewed as familiar sentences because every Monday morning the Pancasila were heard through the flag ceremony at school.

Referring to the results of a survey conducted by the Central Statistics Agency (BPS) on 27-29 May 2011 in 181 Regencies of 33 Provinces by involving 12.056 respondents, it turns out that nine years ago it was known that Indonesian people had minimal national insight, there were 10 percent of the people who had unable to mention the Pancasila precepts in full and only 67-78 percent know about the Unitary State of

\footnotetext{
Sejarah Terintegrasi Pendidikan Multikultural Untuk Membangun Wawasan Kebangsaan," Paramita: Historical Studies Journal, vol. 25, no. 2 (2016), p. 247, https://doi.org/10.15294/paramita. v25i2.5135.(2

14 Hermanu Joebagio, Madhan Anis, Husain Haikal, “Implementasi Wawasan..., pp. 11-22

15 Aniqa Faza, et al., Pengajaran Sejarah Sebagai Media Penanaman Wawasan Kebangsaan ( Studi Kasus Di Kelas XI IPS 2 Syamsul Huda ," vol.8, no. 2 (2017), pp. 1-11.
} 
the Republic of Indonesia and Unity in Diversity. In an article written by Gusti (2015) in the electronic media ugm.ac.id dated December 15, 2015, contains information that the tendency of people not to care about Pancasila is a symptom of the emergence of apathy towards Pancasila which is caused by a lack of example among the elite..$^{16}$

Indeed, since the reforms era in 1998 the nation seemed to lose its identity, political confinement in the New Order regime had pushed groups of people who were oppressed by the anti-Suharto crowd to establish political parties to be used as a means of their struggle to take power constitutionally in this republic. Political parties are born rapidly; some of them do not want to make Pancasila as their main principle, especially Islamic parties affiliated with the Islamic trans-national movement. This shows that our education has not been able to develop Indonesian people and people as expected. History subjects are given with the intention to shape the character and civilization of a nation with dignity and in the formation of Indonesian people, who have a sense of nationalism and love of the homeland, seem to have lost their vision. ${ }^{17}$

From some of the conditions and realities that occur at this time, it is suspected that several factors suspected to be the cause are related to the history teacher's performance which is static with incorrect strategies and methods in the history learning process. Research result ${ }_{18}$ argues that teacher learning methods that make more students who do not like history lessons. According to Suharsaputra ${ }^{19}$ the essence the performance of teachers is the behavior produced by a teacher in carrying out his duties as an educator and teacher when teaching in

${ }^{16}$ Gusti, Armaidy Armawi: Muncul Apatisme Terhadap Pancasila https://ugm.ac.id/id/newsPdf/10877-armaidy-armawimuncul-apatisme-terhadap-pancasila, accessed, march 9, 2020.

17 Nur Rokhman. M, Nurhadi, dan Muhsinatun S, "Pengembangan Kurikulum Pengetahuan Sosial Terpadu secara Tematik di Tingkat SLTP: Sebuah Pemikiran Awal". ISTORIA. Jurnal Pendidikan dan Ilmu Sejarah, vol.1 no.2 (Maret 2006).

${ }^{18}$ Aniqa Faza, et al., Pengajaran Sejarah Sebagai Media..., pp.1-11.

19 Uhar Suharsaputra, Administrasi Pendidikan, (Bandung. Refika: Aditama, 2010), p.147 front of the class, according to certain criteria. The performance of a teacher will appear in everyday situations and conditions. Performance can be seen in aspects of activities in carrying out tasks and the ways or quality in carrying out these activities or tasks.

Teacher performance is the ability demonstrated by the teacher with regard to the roles, tasks and responsibilities that he carries on the basis of his professional abilities. Performance is said to be good and satisfying if the objectives achieved are in accordance with established standards. Assessing the quality of teacher performance can be viewed from several indicators which include: 1) teaching planning, 2) implementing the learning performance, 3) evaluating, and 4) following up. Likewise, the performance of history subject teachers plays an important role in instilling the values of nationalism and national governance.

In addition, the principal's leadership is also a major factor that drives the effective learning process in the classroom, the principal's leadership indirectly contributes to students through supervision by the principal to the teacher's performance in the classroom. The ineffectiveness of historical learning is allegedly also related to leadership headmaster. For this reason, the study of the principal's leadership is important to study. Not only that, even the creation of a conducive school environment cannot be separated from the leadership of the school principal, many research findings suggest that a conducive school environment encourages students to feel comfortable learning and living for long in the school, including the climate of communication between leaders and all school residents. Meanwhile, Pesantren culture also influences the quality of students from the aspects of knowledge, attitudes and behavior of students in social, national and state life. Don't expect students to be born with a spirit of nationalism and love for the motherland and a democratic outlook while Pesantren has a culture that does not interfere at all with the spirit of nationalism and love for the motherland as expected from the aims of learning history. 
Based on the above problems, this study aims to determine the implementation of the history learning process in shaping the younger generation who upholds the spirit of nationalism and patriotism at Pesantren Buya Hamka.

\section{Method}

This research is a combination of survey research with quantitative research using descriptive analysis, correlational and multiple regression methods with the aim to see the implementation stage of the studied variables, and to see the correlational relationships and the influence of some variables that are positioned as independent variables on the dependent variable. This research was conducted at Pesantren Buya Hamka, data obtained from high school students with a total sample of 67 people, which was conducted from December 2019 and January 2020.

This study uses a questionnaire as a research instrument to obtain information about transformational leadership of school principals, conducive school climate, the performance of history teachers, and the culture of Pesantren Buya Hamka and the history of learning processes as well as students' knowledge, attitudes and behavior towards nationalism and patriotism.

The instrument of this study consisted of 16 items of Transformational Leadership variables, School Conducive variables 7 items, Teacher Performance History variables 17 items, Pesantren Buya Hamka Culture variable 5 items, Historical Learning variable 32 items, Knowledge variable 5 items, Attitude variable 5 items, and student behavior variables 5 items with 75 items total overall.

After testing the instrument and repairing it to measure the validity and reliability estimation with Cronbach Alpha based on Wahyu Ningsih's (2015) view, it can be stated that all instrument items have a validity and reliability level that meets the requirements to proceed to the next stage. The test results of the instrument can be seen in Table 1 below:
Tabel 1. Validity and Reliability of Instrument

\begin{tabular}{|c|c|c|}
\hline Variables & Items & $\begin{array}{l}\text { Cronbach } \\
\text { Alpha }\end{array}$ \\
\hline Transformational leadership & 16 & \\
\hline 1. Idealized Influence & 4 & 0.662 \\
\hline 2. Inspirational Motivation & 4 & 0.807 \\
\hline 3. Intellectual Stimulation & 4 & 0.840 \\
\hline 4. Individual Consideration & 4 & 0.610 \\
\hline Favorable School Climate & 7 & 0.919 \\
\hline History Teacher Performance & 17 & \\
\hline 1. Pedagogical Competence & 5 & 0.820 \\
\hline 2. Personality competence & 5 & 0.638 \\
\hline 3. Social Competence & 3 & 0.800 \\
\hline 4. Professional Competence & 4 & 0.795 \\
\hline Pesantren Culture & 5 & 0.607 \\
\hline Historical Learning & 32 & \\
\hline 1. Before Learning & 4 & 0.882 \\
\hline 2. Learning Implementation & 6 & 0.905 \\
\hline 3. Student Activity & 7 & 0.800 \\
\hline 4. Learning methods & 5 & 0.905 \\
\hline 5. Closing Activity Learning & 6 & 0.786 \\
\hline 6. Remedial Activity & 4 & 0.702 \\
\hline $\begin{array}{l}\text { Historical knowledge of students } \\
\text { about Nationalism and Patriotism }\end{array}$ & 5 & 0.708 \\
\hline $\begin{array}{l}\text { Student Attitudes about Nationalism } \\
\text { and Patriotism }\end{array}$ & 5 & 0.907 \\
\hline $\begin{array}{l}\text { Student Behavior about Nationalism } \\
\text { and Patriotism }\end{array}$ & 5 & 0.716 \\
\hline
\end{tabular}

In instruments, a Likert scale of 5 is used to indicate the respondent's agreement on each statement made by the instrument. Respondents need to provide answers to statements made by rounding up numbers on the scale provided. The answer to each statement in each space is stated as follows: 5 = always, $4=$ often, 3 , sometimes, $2=$ very rarely, and $1=$ never and also uses a scale of $5=$ very much agree, $4=$ agree, $3=$ less agree, 2 = disagree, and 1 = strongly disagree.

All data obtained were analyzed using Statistical Package for the Social Sciences (SPSS version 20) using descriptive statistics, inference and regression. Descriptive analysis is used to analyze the stage of implementation of each variable by using min scores and standard 
deviations. The interpretation of the min score is determined based on the scale used by Jamil Ahmad (2002), as in Table 1 below:

Table 2. The interpretation of the min score

\begin{tabular}{cc}
\hline Average Score & Interpretation \\
\hline 1.00 to 1.89 & Very Low (SR) \\
1.90 to 2.69 & Low (R) \\
2.70 to 3.49 & Enough (S) \\
3.50 to 4.29 & High (T) \\
4.30 to 5.00 & Very High (ST) \\
\hline
\end{tabular}

While the Pearson correlation is used to analyze the research hypothesis to determine the strength of the relationship between variables. The finding of the analysis in the form of a relationship that is the value of $r$ is interpreted into 3 stages, namely the low, simple and high stages. The interpretation of $r$ value into three stages can be referred to in the following Table 3.

Table 3. The level of relationship between the two variables

\begin{tabular}{cc}
\hline Correlation Multiplier $(r)$ & Relationship Strength \\
\hline $0.70-1.00$ & High \\
$\pm 0.30-0.69$ & Enough \\
$\pm 0.00-0.29$ & Low
\end{tabular}

Source: Jackson L. Sherry (2006). Research Methods and Statistics. A Critical Thinking Approach. Belmont: Thomson Higher Education US

Stepwise method regression analysis was used to analyze the contribution of four independent variables to effective learning as the dependent variable and the contribution of the independent variable to the knowledge, attitudes, and behavior of nationalism and patriotism of Senior High School students of Pesantren Buya Hamka.

\section{Result and Discussion}

Descriptive analysis is used to see the stage of implementation of each variable with a minimum score and standard deviation. The minimum interpretation score is determined based on the scale determined by Jamil Ahmad (2002), as in Table 1 above. The results showed the implementation stage of the headmaster's transformational leadership at the Pesantren
Buya Hamka at the high school level was at the acquisition of the high stage min score with a score of $\min =3.63$, the results also showed respondents' answers to the four indicators of transformational leadership were at the high stage min score i.e. 1). Idealized Influence with the acquisition of a score of $\min =3.91 ; 2$ ). Inspirational Motivation with the acquisition of a score of $\min =3.96 ; 3$ ) Intellectual Stimulation with the acquisition of a score of $\min =3.93$; Individual Consideration with the acquisition of a score of $\min =4.17$, such as the following table:

Next the results of the study also showed the implementation phase of a conducive school climate in Pesantren Buya Hamka. As stated by Razak $^{20}$ that a conducive school climate is one of the characteristics of an effective school. In this study the characteristics of a conducive school climate are revealed by seven indicators, namely 1). The school environment is clean, beautiful and safe and sufficient means for extra-curricular activities; 2). Students feel happy and comfortable at school; 3). Many students have a positive view of the school program; 4). The school places emphasis on academic achievement 5). School discipline is well controlled; 6 ). History teachers have a high commitment in carrying out history learning; 7). The principal has a creative idea towards continuous school improvement.

Overall six of the seven conducive school climate indicators are at the min grade level High min > 3.50, except for the indicator "Students feel happy and comfortable at school" turns out to be at the min grade stage Very High ( $\mathrm{min}=$ 4.33). This gives the meaning that students give a very agreeable view that what makes them happy and comfortable in school is because the school environment is well organized, classrooms are neatly arranged and sufficient means for extracurricular activities, more importantly the history teacher has a high commitment in carrying out historical learning. As stated by Mortimore ${ }^{21}$ that 12 characteristics of effective schools, one of the

${ }^{20}$ Ahmad Zabidi Abdul Razak, "Cell Pairing on a Microwell Array Electrode by Positive Dielectrophoresis," Cirilklim Sekolah Berkesan: Implikasinya Terhadap Motivasi Pembelajaran, vol. 31 (2006), pp. 3-19, https://doi.org/10.1109/MHS.2014.7006159.

${ }_{21}$ Peter Mortimore, "The International Congress For School Effectiveness and Improvement,” no. Lmi (1993). 
characteristics is a conducive school environment shown by students feeling comfortable in school.

Then the results of research on the performance of history teachers are measured by four competencies are 1) Pedagogic competence; 2) personality competence; 3 ) social competence; 4) professional competence. The result of the analysis showed that each indicator was at the level of high score which high means is at > 3.50. This result gives the respondent meaning that he agrees that the history teacher has a good performance in carrying out history learning in Pesantren Buya Hamka. With regard to pedagogical competence, their history teacher can get to know each student's learning behavior in class and be able to use various techniques to motivate students' willingness to learn about history, next also their history teacher can manage class effectively so that learning activities vary so that attract the attention of students. In personality competency, respondents gave the view that their history teacher was a disciplined person who was always present every hour teaching, starting and ending learning on time and including people who are proud of their profession as history teachers. While in the aspect of social competence it was also stated that according to the observation of the history teacher respondent was a person who was sociable in maintaining relationships and maintaining good relations and caring with peers and contributing positively to school progress.

Finally, in the aspect of professional competence, their history teacher is a teacher who master's historical material, is skilled and fluent in carrying out learning activities. This finding is in accordance with the characteristics of professional teachers, namely teachers who focus on learning, teachers who carry out serious learning, teachers who have high expectations of student achievement, and teachers who carry out continuous assessment ${ }^{22}$.

The results of this study indicate the implementation phase of Pesantren Buya Hamka culture is at a high min score 3.50 to .24 .29 for

${ }^{22}$ Pam Sammons, Josh Hillman, and Peter Mortimore, Key Characteristics of Effective Schools: A Review of School Effectiveness Research, North, 1995. indicators: 1) Islamic boarding schools teach about Islamic teachings more oriented to Muhammadiyah as a modernist and tajdîd Islamic movement; 2) Buya Hamka Islamic Boarding School also teaches about Muhammadiyaan; 3) The dawn prayer at Pesantren is without qunut, there is no tahlilan ritual, and the haul commemorative tradition of haul leaders; 4) Students interested in studying at this Pesantren inspired by Buya Hamka's figure as a great scholar of Muhammadiyah and his role models in social life. As for the indicator 5) The head of the Integrated Modern Pesantren, Buya Hamka, is led by a person who holds a modernist view of Islam at a very high min score ( $\mathrm{min}=$ 4.34). The results of this study illustrate that all respondents' answers are in the stage of agreeing to four indicators and the stage of strongly agreeing to the indicators of Pesantren Buya Hamka led by a person who holds a modernist view of Islam". This means they strongly agree that someone who heads the Pesantren Buya Hamka does not have to be a Kiyai or a Sech but rather someone who is knowledgeable academically and has a modernist outlook on Islam. Those respondents were also inspired to enter this Pesantren because of Buya Hamka's figure as a great scholar of Muhammadiyah and his role models in social life. Another meaning that can be revealed is that respondents gave the same perception that the culture that developed in the Pesantren Buya Hamka was oriented to the values of the Muhammadiyaan as a modernist and tajadid Islamic organization and the figure and the Buya Hamka leadership.

Meanwhile, regarding the implementation of the history learning process at Pesantren Buya Hamka, the results of the overall analysis are at the Very High min score $(\min =4.50)$. Of the six indicators of historical learning variables, three indicators are at a high stage with a score of min $>3.50$ to $\min \leq 4.29$, while three indicators are at a very high stage score mean $>4.30$ to $\min 5.00$. In the process of learning history starting from activities before learning begins, the ongoing learning process, student activities in learning, and methods used by history teachers, up to the activities of closing learning according to the views of respondents the history teacher has 
implemented the learning process effectively. Likewise, the remedial action given by the history teacher to students who have not yet finished learning and the enrichment of students quickly in learning according to the respondents' views has been carried out well by the history teacher.

Then to know the implementation stage of the output of a history learning process seen by indicators of the extent to which respondents have knowledge and understanding of national history with a focus on knowledge and understanding of nationalism and patriotism. This knowledge is measured by five historical questions. To measure the extent to which knowledge about nationalism and patriotism influences the attitudes and behavior of respondents in responding to various problems in social, national and state life, it is also measured by 10 questions that can measure respondents' attitudes and behavior about Pancasila as the final state of the State, harmony of life as a nation and state, as well as attitudes and behaviors towards communism, state of the khilafah and radicalism.

The results of the analysis of respondents' understanding of nationalism and patriotism knowledge as a whole are at a score of $\min =$ 4.92 Very High stage. Likewise for each indicator is also at the min score Very High stage. The results of respondents' answers show that they have knowledge that Indonesian independence on 17 August 1945 was the result of the struggle of the Indonesian people from various ethnic groups, languages and religions who had stated their determination to unite as one nation, one language and one homeland, namely Indonesia on October 28, 1928 Then the respondent also knew that when the Jakarta Charter was established as the Basis of the Nation by PPKI there had been debates about the first precept. For the sake of national unity and integrity, four members of the PPKI representing Muslims were willing to compromise and correlate and accept the change in the first precept "Divinity with the obligation to carry out Islamic law for its adherents" was changed to the Almighty God alone. Pancasila has been agreed to be the basis of the state and the ideology of the Unitary State of the Republic of Indonesia (NKRI) by the founder of this country and it is final that it cannot be changed. Indonesia is a country of nationality and diversity, the efforts of certain groups to make Indonesia a state based on Islam or a communist state are radical actions that contradict national values and Pancasila as the state ideology. The state recognizes the existence of all religions in Indonesia, namely Islam, Christianity, Catholicism, Hinduism, Buddhism. Therefore, tolerance in social and religious life must be respected by all ethnic groups, religious groups.

From their knowledge of the history of Indonesian nationality, their answers can also express their attitude as good citizens who have high nationalism and a spirit of patriotism. The results of the analysis show that indicators in the form of negative statements can be responded to by giving a response that strongly disagrees with the following indicators: 1) Indonesia's Independence on 17 August 1945 was the result of the struggle of the majority of Muslims; 2) The first precept of the Jakarta Charter is the Godhead with the obligation to carry out Islamic Sharia for its adherents to be fit as the first precepts of the Pancasila because the majority of Indonesian people are Muslim; 3) Pancasila which has been agreed to be the basis of the state and the ideology of the Unitary State of the Republic of Indonesia (NKRI) by the founder of this country is not an absolute agreement, it may be changed if the majority of Indonesian people adhere to Islam wants; 4) As a nationality with a majority of Muslims, it is only natural that community organizations or political parties make Islam a principle of movement or struggle; 5) Indonesian Muslims as the majority population are reasonable not to give greetings of Christmas or happy birthday to followers of other religions. Respondents' answers give meaning that Pesantren Buya Hamka students giving conflicting or disagreeing responses to the five negative indicators reflect their point of view in accordance with the Islamic spirit of Muhammadiyah as a modernist and tajdid and accommodating Muslim organization and far from attitude radicalism.

Likewise, respondent behavior is also measured by five statements describing the 
respondent's behavior in responding to the issue of nationality, the principle of Pancasila, alternative ideology, religious tolerance, and communism and radicalism. Respondents' responses to all indicators are at the Very High min score stage. Respondents gave answers very much agree with the following five statements, namely 1) Indonesia is a country based on Pancasila; therefore, I disagree if there are principles of the struggle of social organizations and political parties not based on Pancasila; 2) I oppose any attempt by community groups who seek to change Pancasila as a state ideology and replace it with another ideology; 3) I do not show hostility towards adherents of other religions (Christian, Catholic, Hindu, Buddhist) when they perform worship according to their beliefs; 4) I will fight every form of activity that seeks to revive the PKI in Indonesia; 5) I gave a Christmas greeting for consideration of religious tolerance even though I knew that action was not permitted by Islamic teachings.

Furthermore Pearson correlation analysis is used to test the H1-1 through H1-4 hypotheses. To facilitate the description of the results of correlational analysis, the strength of the relationship ( $r$ ) is interpreted into 3 stages: the low weak stage, simple stage and high stage. The interpretation of the value $(r)$ into three stages can be seen in Table 2 above.

Table 4 below, shows that there is a significant relationship $(r=0.353$ and Sig. $=0.000$ $<0.05$ ) between transformational leadership and history learning with correlation at a simple stage.

Table 4. Pearson correlation analysis among four independent variables to the dependent variable as a whole

\begin{tabular}{lccc}
\hline $\begin{array}{l}\text { Relationship between two } \\
\text { variables }\end{array}$ & $\mathbf{r}$ & Sig. & Stage \\
\hline $\begin{array}{l}\text { Transformational leadership } \\
\text { with history learning }\end{array}$ & 0.353 & 0.003 & Enough \\
\hline $\begin{array}{l}\text { The school climate is } \\
\text { conducive to learning } \\
\text { history }\end{array}$ & 0.937 & 0.000 & High \\
\hline $\begin{array}{l}\text { History teacher } \\
\text { performance with history } \\
\text { learning }\end{array}$ & 0.368 & 0.002 & Enough \\
\hline $\begin{array}{l}\text { Pesantren Buya Hamka } \\
\text { culture with history } \\
\text { learning }\end{array}$ & 0.690 & 0.000 & Enough \\
\hline
\end{tabular}

\begin{tabular}{|c|c|c|c|}
\hline $\begin{array}{c}\text { Relationship between two } \\
\text { variables }\end{array}$ & $r$ & Sig. & Stage \\
\hline $\begin{array}{l}\text { Transformational leadership } \\
\text { with the history teacher's } \\
\text { performance }\end{array}$ & 0.968 & 0.000 & High \\
\hline $\begin{array}{l}\text { The school climate is } \\
\text { conducive to the history } \\
\text { teacher's performance }\end{array}$ & 0.337 & 0.005 & Enough \\
\hline $\begin{array}{l}\text { Pesantren Buya Hamka } \\
\text { culture with the } \\
\text { performance of history } \\
\text { teachers }\end{array}$ & 0.302 & 0.013 & Enough \\
\hline $\begin{array}{l}\text { Transformational leadership } \\
\text { with knowledge of } \\
\text { nationalism and patriotism }\end{array}$ & 0.311 & 0.003 & Enough \\
\hline $\begin{array}{l}\text { The school climate } \\
\text { is conducive to the } \\
\text { knowledge of nationalism } \\
\text { and patriotism }\end{array}$ & 0.885 & 0.000 & High \\
\hline $\begin{array}{l}\text { Performance of history } \\
\text { teachers with knowledge } \\
\text { of nationalism and } \\
\text { patriotism }\end{array}$ & 0.325 & 0.007 & Enough \\
\hline $\begin{array}{l}\text { Pesantren culture with } \\
\text { knowledge of nationalism } \\
\text { and patriotism }\end{array}$ & 0.605 & 0.000 & Enough \\
\hline $\begin{array}{l}\text { Learning history with } \\
\text { knowledge of nationalism } \\
\text { and patriotism }\end{array}$ & 0.952 & 0.000 & High \\
\hline $\begin{array}{l}\text { Transformational leadership } \\
\text { with an attitude of } \\
\text { nationalism and patriotism }\end{array}$ & 0.328 & 0.007 & Enough \\
\hline $\begin{array}{l}\text { The school climate is } \\
\text { conducive to nationalism } \\
\text { and patriotism }\end{array}$ & 0.952 & 0.000 & High \\
\hline $\begin{array}{l}\text { Performance of history } \\
\text { teachers with an attitude } \\
\text { of nationalism and } \\
\text { patriotism }\end{array}$ & 0.330 & 0.006 & Enough \\
\hline $\begin{array}{l}\text { Pesantren culture with an } \\
\text { attitude of nationalism and } \\
\text { patriotism }\end{array}$ & 0.740 & 0.000 & High \\
\hline $\begin{array}{l}\text { Learning history with an } \\
\text { attitude of nationalism and } \\
\text { patriotism }\end{array}$ & 0.922 & 0.000 & High \\
\hline $\begin{array}{l}\text { Transformational leadership } \\
\text { with nationalism and } \\
\text { patriotism }\end{array}$ & 0.127 & 0.306 & $\begin{array}{l}\text { Low } \\
\text { and not } \\
\text { significant }\end{array}$ \\
\hline $\begin{array}{l}\text { The school climate is } \\
\text { conducive to nationalism } \\
\text { and patriotism }\end{array}$ & 0.193 & 0.119 & $\begin{array}{l}\text { Low } \\
\text { and not } \\
\text { significant }\end{array}$ \\
\hline $\begin{array}{l}\text { Performance of history } \\
\text { teachers with nationalism } \\
\text { and patriotism }\end{array}$ & 0.116 & 0.352 & $\begin{array}{l}\text { Low } \\
\text { and not } \\
\text { significant }\end{array}$ \\
\hline $\begin{array}{l}\text { Pesantren culture with } \\
\text { nationalism and patriotism } \\
\text { behavior }\end{array}$ & 0.183 & 0.139 & $\begin{array}{l}\text { Low } \\
\text { and not } \\
\text { significant }\end{array}$ \\
\hline $\begin{array}{l}\text { Learning history with } \\
\text { nationalism and patriotism }\end{array}$ & 0.326 & 0.007 & Enough \\
\hline
\end{tabular}


The manifest a significant relationship $(r=$ 0.937 and Sig. $=0.000<0.05)$ at a high stage between a conducive school climate and learning history, then there is a significant relationship $(r=0.368$ and Sig. $=0.000<0.05)$ in a simple stage between teacher performance with history learning and a significant relationship $(r=0.690$ and Sig. $=0.000<0.05)$ at a simple stage between the culture of Pesantren Buya Hamka and learning history.

While the results of correlation analysis between transformational leadership variables, history teacher performance, Pesantren culture are correlated with knowledge of nationalism and student patriotism at simple stages $(r=>$ $0.30-\leq 0.69$ and Sig. $=0.000<0.05)$. While the conducive school climate and history learning correlate with the nationalism and patriotism variables of Pesantren Buya Hamka students at a high level $(r=>0.70$ and Sig. $=0.000<0.05)$.

The results of the correlation analysis between transformational leadership variables and the performance of history teachers correlate with attitudes of nationalism and patriotism of students at a simple stage $(r=>0.30-\leq 0.69$ and Sig. $=0.000$ $<0.05$ ). While the conducive school climate variable, Pesantren Buya Hamka culture, history learning correlate with the nationalism and patriotism variables of Pesantren Buya Hamka at the High School students is at a high stage $(r=>0.70$ and Sig. $=0.000<0.05)$. Finally, the transformational leadership variable of school principals, conducive school climate, teacher performance, and Pesantren Buya Hamka culture did not correlate significantly with student nationalism and patriotism variables, while historical learning variables correlated at simple stages $(r=0.326$ and Sig. $=0.000<0.05)$ with the nationalism and patriotism behavior of Pesantren Buya Hamka students.

Correlation analysis results like Table 4 below show that all independent variables correlate with dependent variables, but there are four variables that correlate at low and insignificant stages, namely transformational leadership of school principals, conducive school climate, performance of history teachers, and the culture of Islamic Boarding School Hamka correlates at a low stage with nationalism and patriotism behavior of students but is not significant. These results give the meaning that the four variables do not touch directly in shaping the behavior of students about nationalism and nationalism love or nationalism. Behavior formation can only be done directly by the history teacher in the form of providing examples and examples of the spirit of nationalism and patriotism to students and not in the form of mastery of knowledge that is still in the cognitive realm. As explained by research ${ }^{23}$ that the leadership of a school principal does not contribute directly to student behavior, but changes can be made through the supervision of the learning process carried out by the teacher in the classroom. Likewise the Pesantren culture that reflects the characteristics of Pesantren Buya Hamka does not directly influence the improvement of student behavior but through the learning process implemented by the teacher in the classroom.

In order to see the value of the influence of variables (1) Principal Transformational Leadership, (2) Conducive School Climate, (3) History Teacher Performance, (4) Pesantren Buya Hamka Culture, and (5) Historical Learning Process on nationalism knowledge used regression analysis multiple with the stepwise method. The stepwise method only measures the independent variables that have a significant effect on the dependent variable, which is not influential, and will be removed directly by regression. The results of the analysis show that of the five variables analyzed, only one independent variable, namely History Learning by the teacher, has a significant effect in instilling nationalism knowledge with the value of influence can be seen in item 5 below.

Tabel 5. ANOVA Varians Analysis of Independent towards Dependent Variables

\begin{tabular}{lllllll}
\hline \multirow{2}{*}{ Model } & $\begin{array}{c}\text { Sum of } \\
\text { Squares }\end{array}$ & df & $\begin{array}{c}\text { Mean } \\
\text { Square }\end{array}$ & F & Sig. \\
\hline \multirow{3}{*}{1} & Regression & 20.080 & 1 & 20.080 & 624.161 & $.000^{b}$ \\
\cline { 2 - 7 } & Residual & 2.091 & 65 & .032 & & \\
\cline { 2 - 7 } & Total & 22.171 & 66 & & \\
\hline
\end{tabular}

a. Dependent Variable: Nationalism Knowledge

b. Predictors: (Constant), Learning History

23 Vali Mehdinezhad and Masoumeh Mansouri, "School Principals' Leadership Behaviours and Its Relation with Teachers' Sense of Self-Efficacy," International Journal of Instruction, vol. 9, no. 2 (2016), pp. 51-6o, https://doi.org/10.12973/iji.2016.924a. 
The results of the analysis as in Table 6 above, show analysis of variance with values $\mathrm{F}$ $=624,161$ and sig $=0.00<0.05$.

Table 6. Stepwise regression for all independent variables on nationalism knowledge as the dependent variable

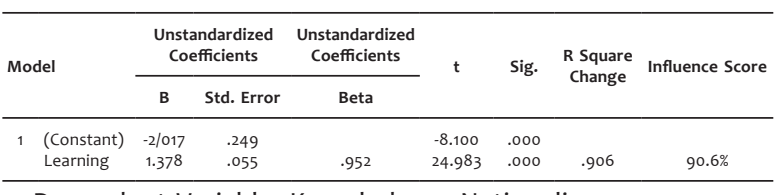

a. Dependent Variable: Knowlede on Nationalism

This finding shows the learning process carried out by the history teacher becomes a predictor of the inculcation of historical knowledge about nationalism understanding of Pesantren Buya Hamka students, while four more variables do not become predictors of the history teacher learning process. These findings prove $\mathrm{H}_{1} 5$ for historical learning variables accepted.

The value of contributions made through the history teacher learning process towards students' nationalism knowledge shown in Table 6 is Beta $=0.952, t=24,983$, sig $=0.00<0.05$ and $R_{2}=0.906$. This finding shows that the teacher learning process influences students' nationalism knowledge by $90.6 \%$, while the remaining $9.4 \%$ is caused by other variables. Another conclusion that can be drawn from the results of this analysis is that if the learning process increases by 1 unit, the student's nationalism knowledge stage will also increase by 0.952 units. The regression equation that can be made for the results of this analysis is as follows:

$$
\begin{aligned}
& \mathrm{Y}=-2,017+1,378 \mathrm{X}+0.055 \\
& \mathrm{Y}=\text { Nationalism and patriotism } \\
& \mathrm{X}=\text { History Learning Process } \\
& \mathrm{R}^{2} \text { Double }=0.906 \\
& \text { Constant }=-2,017 \\
& \text { Correct Default (Standard Error) } 0.055
\end{aligned}
$$

Next, the extent to which the influence of students 'knowledge variables on nationalism and love for the motherland (nationalism and patriotism) influences the attitude of students' nationalism and patriotism analyzed by the enter method can be seen in item 7 below.
Table 7. ANOVA Variance of knowledge variables on attitudes

\begin{tabular}{llccccc}
\hline Model & $\begin{array}{c}\text { Sum of } \\
\text { Squares }\end{array}$ & df & $\begin{array}{c}\text { Mean } \\
\text { Square }\end{array}$ & F & Sig. \\
\hline \multirow{3}{*}{11} & Regression & 21.821 & 1 & 21.821 & 214.078 & .000 \\
\cline { 2 - 7 } & Residual & 6.625 & 65 & .102 & & \\
\cline { 2 - 6 } & Total & 28.447 & 66 & & & \\
\hline
\end{tabular}

a. Dependent Variable: Attitude

b. Predictors: (Constant), Knowledge

The results of the analysis as in Table 7 above, show the analysis of variance with the value of $F$ $=214,078$ and sig $=0.00<0.05$ for the nationalism and patriotism knowledge variables. This finding shows that the knowledge variable becomes a predictor for the inculcation of nationalism and patriotism attitude at Hamka Islamic Boarding School students. This finding proves $\mathrm{H} 16$ was accepted.

The value of the contribution given by the

\begin{tabular}{|c|c|c|c|c|c|c|c|}
\hline \multirow[t]{2}{*}{ Model } & \multicolumn{2}{|c|}{$\begin{array}{l}\text { Unstandardized } \\
\text { Coefficients }\end{array}$} & \multirow{2}{*}{$\begin{array}{c}\text { Standardized } \\
\text { Coefficients }\end{array}$} & \multirow[t]{2}{*}{$\mathrm{t}$} & \multirow[t]{2}{*}{ Sig. } & \multirow{2}{*}{$\begin{array}{c}\mathrm{R} \\
\text { Square } \\
\text { Change }\end{array}$} & \multirow[t]{2}{*}{$\begin{array}{l}\text { Influence } \\
\text { Score }\end{array}$} \\
\hline & B & Std. Error & & & & & \\
\hline (Constant) & .108 & .286 & & .337 & .708 & & \\
\hline knowledge & .992 & .068 & .876 & 14.631 & .000 & .767 & $76.7 \%$ \\
\hline
\end{tabular}
knowledge variables to students' nationalism and patriotism attitudes shown in Table 8 is Beta $=$ $0.876, \mathrm{t}=14.631$, sig $=0.00<0.05$ and $\mathrm{R} 2=0.767$.

Table 8. Stepwise regression of knowledge variables on the attitude of nationalism and patriotism

The findings indicate that a conducive school climate influences the attitude of student nationalism by $76.7 \%$, while, the remaining $24 \%$ is caused by other variables. Another conclusion that can be drawn from the results of this analysis is that if knowledge increases by 1 unit, the attitude of student nationalism will also increase by .876 units. The regression equation that can be made for the results of this analysis is as follows:

$$
\begin{aligned}
& \mathrm{Y}=0.108+0.992 \mathrm{X}+0.068 \\
& \mathrm{Y}=\text { Nationalism and patriotism } \\
& \mathrm{X}=\text { Knowledge } \\
& \mathrm{R}^{2} \text { Multiple }=.767 \\
& \text { Constant }=0.108
\end{aligned}
$$

Rectification (Standard Error) 0.068 
Next, the extent of the influence of attitude variables on changes in nationalism and patriotism behavior of students is used the regression analysis of enter method, which can be seen in item 9 below.

Table 9. ANOVA Variance variable attitude towards behavior

\begin{tabular}{llccccc}
\hline Model & $\begin{array}{c}\text { Sum of } \\
\text { Squares }\end{array}$ & df & $\begin{array}{c}\text { Mean } \\
\text { Square }\end{array}$ & F & Sig. \\
\hline \multirow{3}{*}{1} & Regression & 0.056 & 1 & 0.056 & 1.883 & $0.175^{\mathrm{b}}$ \\
\cline { 2 - 7 } & Residual & 1.920 & 65 & 0.030 & & \\
\cline { 2 - 6 } & Total & 1.976 & 66 & & & \\
\hline
\end{tabular}

a. Dependent Variable: Behavior

b. Predictors: (Constant), Attitudes

The results of the analysis as in Table 9 above, show the analysis of variance with $F=1,883$ and $\operatorname{sig}=0.175>0.05$ for the attitude variable. These findings indicate the attitude variable does not become a predictor of the formation of nationalism and patriotism behavior of Hamka Islamic Boarding School students. This finding proves $\mathrm{H}_{1} 6$ was rejected

The value of the contribution given by the attitude variables towards student nationalism and patriotism behavior shown in Table 10 is Beta $=0.168, t=1.7372$, sig $=0.175>0.05$ and $R_{2}=0.028$.

Table 10. Stepwise Regression for Attitudes Variables towards Nationalism and Patriotism Behavior

\begin{tabular}{|c|c|c|c|c|c|c|c|}
\hline \multirow[t]{2}{*}{ Model } & \multicolumn{2}{|c|}{$\begin{array}{l}\text { Unstandardized } \\
\text { Coefficients }\end{array}$} & \multirow{2}{*}{$\begin{array}{c}\text { Standardized } \\
\text { Coefficients } \\
\text { Beta }\end{array}$} & \multirow[t]{2}{*}{$\mathrm{t}$} & \multirow[t]{2}{*}{ Sig. } & \multirow[t]{2}{*}{$\begin{array}{l}\text { R Square } \\
\text { Change }\end{array}$} & \multirow{2}{*}{$\begin{array}{c}\text { The } \\
\text { Scores on } \\
\text { influence }\end{array}$} \\
\hline & B & $\begin{array}{l}\text { Std. } \\
\text { Error }\end{array}$ & & & & & \\
\hline (Constant) & 4.740 & 0.139 & & 34.17 & 0.00 & & \\
\hline Attitudes & 0.044 & 0.032 & 0.168 & $\begin{array}{r}9 \\
1.737 \\
2\end{array}$ & 0.175 & 0.028 & $2.8 \%$ \\
\hline
\end{tabular}

This finding shows that attitude does not significantly influence the nationalism behavior of students. Another conclusion that can be drawn rather than the results of this analysis is that the attitude variable is constant towards the insight of nationalism and love for the motherland. Therefore, the behavior of a student in responding to various problems related to nationalism and patriotism is not linear with one's attitude. Attitudes regarding a person's judgment of right and wrong, bad and good, but a person's behavior can be different from the attitude of context considerations. A student of the Islamic Boarding School Hamka has the attitude that giving Christmas greetings to nonMuslim neighbors is contrary to the beliefs and teachings of the religion they profess, but based on the consideration of tolerance in social life they may behave differently from their attitudes.

\section{Conclusion}

From some of the findings of this study, it can be concluded that from the process approach based on the evaluation of the CIPP model (Context, Input, Process and Output) by Stufflebeam (1985) as a whole the implementation phase of the transformational leadership of the school, conducive school climate, performance of history teachers, Pesantren culture as well as the history learning process according to respondents' assessments has been carried out well with min scores at a high stage. From the output approach it can be stated that Pesantren Buya Hamka for the high school students have good knowledge and understanding of national history, especially those related to nationalist insight (nationalism) and patriotism. They have good knowledge that Indonesian independence on 17 August 1945 was the result of the struggle of the Indonesian people from various ethnic groups, languages and religions who had stated their determination to unite as one nation, one language and one homeland, namely Indonesia on October 28,1928 . Then they also knew that the Jakarta Charter which was established as the Basis of the Nation by the PPKI was the result of compromise and tolerance from the founder of the country and accepted the first change in the principle of "the Godhead with the obligation to carry out Islamic law for its adherents" to be changed to a Godhead. Pancasila has been agreed to be the basis of the state and the ideology of the Unitary State of the Republic of Indonesia (NKRI) which is final must not be changed. Then they also have good knowledge that Indonesia is a country of nationality and diversity, the efforts of certain groups to make Indonesia a state based on Islam or a communist state are radical actions that contradict national 
values and Pancasila as a state ideology. The state recognizes the existence of all religions in Indonesia, namely Islam, Christianity, Catholicism, Hinduism, Buddhism. Therefore, tolerance in social and religious life must be respected by all ethnic groups, religious groups.

Then the good knowledge and understanding of Pesantren Buya Hamka students towards nationalism and patriotism also significantly influence their attitude changes towards nationalism and patriotism. But the change in attitude did not significantly influence the change in student behavior. Attitude is a constant attitude towards nationalism and love for the motherland. Therefore, the behavior of a student in dealing with various problems related to nationalism and patriotism is not linear with one's attitude. Attitudes regarding a person's judgment of right and wrong, bad and good, but a person's behavior can be different from the attitude of context considerations. A student of Pesantren Buya Hamka has the attitude that giving a Christmas greeting to non-Muslim neighbors is contrary to the beliefs and teachings of the religion they profess, but based on the consideration of tolerance in social life they may behave differently from their attitudes.

\section{References}

Anis, Madhan, Husain Haikal, Hermanu Joebagio, "IMPLEMENTASI WAWASAN KEBANGSAAN DALAM PEMBELAJARAN SEJARAH DI PONDOK PESANTREN." Society, 2013, 11-22.

Bandarsyah, Desvian, "Fondasi Filosofis Pendidikan Sejarah Di Era Post Truth." Historia: Jurnal Pendidik Dan Peneliti Sejarah, vol. 3, no. 1, 2019, https://doi.org/10.17509/historia. v3i1.21042.

Faza, Aniqa, Tuty Maryati, Ketut Sedana Arta, S Pd, and M Pd. "Pengajaran Sejarah Sebagai Media Penanaman Wawasan Kebangsaan (Studi Kasus Di Kelas XI IPS 2 Syamsul Huda)," vol.8, no. 2, 2017.

Gusti, "Armaidy Armawi: Muncul Apatisme Terhadap Pancasila” https://ugm.ac.id/id/ newsPdf/10877-armaidy-armawi-munculapatisme-terhadap-pancasila, accessed, March 9, 2020.
Magdalia, Alfian, "Pendidikan Sejarah Dan Permasalahan Yang Dihadapi." Jurnal Ilmiah Kependidikan III, no. 2, 2011. https://doi. org/10.30595/jkp.v3i2.643.

Mehdinezhad, Vali, and Masoumeh Mansouri, "School Principals' Leadership Behaviours and Its Relation with Teachers' Sense of SelfEfficacy." International Journal of Instruction, vol. 9, no. 2, 2016. https://doi.org/10.12973/ iji.2016.924a.

Munir, Miftakhul, "Modernisasi Pendidikan Islam Dalam Perspektif Nurcholish Madjid." Journal EVALUASI, vol. 1, no. 2, 2018. https://doi. org/10.32478/evaluasi.v1i2.73.

Musadad, Akhmad Arif, "Model Manajemen Pembelajaran Sejarah Terintegrasi Pendidikan Multikultural Untuk Membangun Wawasan Kebangsaan," Paramita: Historical Studies Journal, vol. 25, no. 2, 2016. https://doi. org/10.15294/paramita.v25i2.5135.

Peter Mortimore, "The International Congress For School Effectiveness and Improvement," no. Lmi , 1993.

Rokhman, Nur. M, Nurhadi, dan Muhsinatun S, "Pengembangan Kurikulum Pengetahuan Sosial Terpadu secara Tematik di Tingkat SLTP: Sebuah Pemikiran Awal". ISTORIA. Jurnal Pendidikan dan IImu Sejarah, vol.1 no.2, Maret 2006.

Razak, Ahmad Zabidi Abdul, "Cell Pairing on a Microwell Array Electrode by Positive Dielectrophoresis," Ciri Iklim Sekolah Berkesan: Implikasinya Terhadap Motivasi Pembelajaran, vol. 31, 2006. https://doi.org/10.1109/ MHS.2014.7006159.

S, Leo Agung, "Berbasis Pendidikan Karakter Di Solo Raya ( Development History of Sma- Based Learning Model in Solo Raya Character Education )," Jurnal Pendidikan Dan Kebudayaan, vol. 18, no. 4, 2012.

Sammons, Pam, Josh Hillman, and Peter Mortimore, Key Characteristics of Effective Schools: A Review of School Effectiveness Research. North, 1995.

Sumaludin, Muhammad Maman, "Identitas Nasional Dalam Buku Teks Pelajaran Sejarah." Historia: Jurnal Pendidik Dan Peneliti Sejarah, vol. 1, no. 2, 2018. https://doi.org/10.17509/ historia.v1i2.10709. 
Suswandari, "Paradigma Pendidikan Sejarah Dalam Menghadapi Tantangan Masa Depan." Jurnal Cakrawala Pendidikan, vol. 1, no. 1, 2010. https://doi.org/10.21831/cp.v1i1.216.

Suharsaputra, Uhar, Administrasi Pendidikan, Bandung: Refika Aditama, 2010.

Widayanti, Windy Putri, Armaidy Armawi, and Budi Andayani, "Wawasan Kebangsaan Siswa Sekolah Menengah Atas Dan Implikasinya Terhadap Ketahanan Pribadi Siswa (Studi Pada Siswa Sekolah Menengah Atas (SMA) Umum Berasrama Berwawasan Nusantara,
SMA Umum Di Lingkungan Militer Dan SMA Umum Di Luar Lingkungan Militer Di K." Jurnal Ketahanan Nasional, vol. 24, no. 1, 2018.. https://doi.org/10.22146/jkn.32229.

Widja, I Gde, "Pembelajaran Sejarah Yang Mencerdaskan : Suatu Alternatif”, vol. 1, no. 2 (n.d.).

Zed, Mestika, "Tentang Konsep Berfikir Sejarah." Lensa Budaya: Jurnal Ilmiah Ilmu-llmu Budaya, vol. 13, no. 1, 2018. http://dx.doi.org/10.34050/ jlb.v13i1.4147. 